\title{
Development of acute cholecystitis following laparoscopic partial cholecystectomy
}

Oktay Karaköse', Mehmet Zafer Sabuncuoğlu², Mehmet Fatih Benzin², Girayhan Çelik², Mahmut Bülbül², Hüseyin Pülat ${ }^{1}$

\section{ABSTRACT}

Cite this paper as: Karaköse 0, Sabuncuoğlu MZ, Benzin MF, Çelik G, Bülbül M, Pülat H. Development of acute cholecystitis following laparoscopic partial cholecystectomy. Turk J Surg 2017; 33: 209-211.

'Division of Surgical Oncology, Süleyman Demirel University School of Medicine, Isparta, Turkey 2Department of General Surgery, Süleyman Demirel University School of Medicine, Isparta, Turkey

Address for Correspondence Oktay Karaköse e-mail: oktaykarakose@gmail.com Received: 06.01.2015 Accepted: 06.02.2015 Available Online Date: 14.07.2015

oCopyright 2017 by Turkish Surgical Association Available online at www.turkjsurg.com
In cases where the dissection of Calot's triangle is difficult during laparoscopic cholecystectomy, laparoscopic partial cholecystectomy is an alternative to total cholecystectomy to prevent bile duct damage. However, recurrent symptoms and bile duct problems associated with the remaining gallbladder tissue may develop in patients over time. The case of a 45-year-old male who underwent laparoscopic partial cholecystectomy one year previously is presented here. In the postoperative period, as a result of tests for the continuing symptoms of cholecystitis, stones and surrounding abscess were detected in the remaining gallbladder tissue, so open completion cholecystectomy was applied. In acute cholecystitis, as severe inflammation of the hilar structures does not allow safe dissection, partial cholecystectomy can be applied. However, in these patients, there is a risk of recurrence of cholecystitis symptoms and the development of biliary pancreatitis and choledocolithiasis because of the remaining tissue. Therefore, it should not be forgotten that endoscopic and/or surgical intervention may be necessary at least in some patients.

Keywords: Laparoscopic cholecystectomy, partial, subtotal, completion, acute cholecystitis

\section{INTRODUCTION}

Open or laparoscopic partial cholecystectomy has been reported to be a safe and effective operation as an alternative to total cholecystectomy in cases where intraoperative findings or variations in anatomy do not allow the safe dissection of Calot's triangle $(1,2)$. It is known as subtotal cholecystectomy. It is indicated when the bile duct structures cannot be evaluated because of inflammation in severe acute cholecystitis or necrotizing or gangrenous cholecystitis $(1,2)$. The majority of the gallbladder is removed, and a part of the neck section or gallbladder posterior wall is left in place depending on the inflammation (3). As there may be postoperative minor symptoms that can be tolerated, recurrent acute cholecystitis symptoms may lead to significant problems such as choledocolithiasis or persistent biliary fistula (4).

Even if partial cholecystectomy is technically possible, the ideal procedure is the total removal of the gallbladder (5-7). As new stones may form in the attachment of the gallbladder to the choledochus, the amount of remaining tissue may cause stump cholecystitis, choledocolithiasis, or persistent biliary colic (5).

The case of a patient with continuing symptoms after laparoscopic partial cholecystectomy is presented here, and as cholecystitis and an adjacent intra-abdominal abscess has developed in the gallbladder, completion cholecystectomy was performed.

\section{CASE PRESENTATION}

A 45-year-old male underwent laparoscopic cholecystectomy at another clinic 12 months previously. Despite the operation, complaints of abdominal pain and nausea continued in the postoperative period. As the complaints increased in the previous month, tests were performed. On abdominal ultrasonography, a solid mass of calcifications was determined in the lateral left lobe of the liver. Computed tomography (CT) was performed, and a $6 \mathrm{~cm} \times 6 \mathrm{~cm}$ cystic lesion was seen in segment 4-5 of the liver around the metallic clips adjacent to the gallbladder fossa, and to the medial of this lesion, a second multiseptal cystic lesion of $7 \mathrm{~cm} \times 6 \mathrm{~cm}$ was seen in the first part of the duodenum wall and stomach antrum (Figure 1). Adjacent to the lesions, an area of $2 \mathrm{~cm} \times 3 \mathrm{~cm}$ calcification was seen (Figure 2). It was anticipated that the patient would undergo total cholecystectomy because there could be a hydatid liver cyst or intra-abdominal infection because of gallbladder stones scattered in the abdomen. The patient was operated on with these findings. In the exploration, a mass was revealed over the omentum between the liver and the small curvature of the stomach. When adhesions were opened, abscess drainage from this area was performed. A $3 \mathrm{~cm}$ stone was seen in the Hartmann's pouch of the gallbladder inside the open lumen. It was understood that a partial cholecystectomy had been performed on the patient. A completion cholecystectomy was performed, and the patient was discharged on the $4^{\text {th }}$ day postoperatively without any medical problem. 


\section{DISCUSSION}

In acute cholecystitis, as severe inflammation does not allow the safe dissection of the hilar structures, partial cholecystectomy can be performed $(1,2)$. In the study by Kaplan et al. (1) who compared subtotal cholecystectomy with open cholecystectomy in patients with complicated cholecystitis, the rate of serious complications (damage to the common hepatic canal, vascular damage, and gastrointestinal damage) was found to be higher in the patients who underwent open cholecystectomy ( $7.9 \%$ vs. $0 \%$ ). To avoid complications that may develop in cases of complicated cholecystitis demanding total cholecystectomy, subtotal cholecystectomy was recommended, and the conclusion that it could be applied as a safe alternative was reached. In a meta-analysis by Elshaer et al. (8), indications for subtotal cholecystectomy were severe cholecystitis $(72.1 \%)$, cholelithiasis in liver cirrhosis and portal hypertension $(18.2 \%)$, and empyema or perforated gallbladder (6.1\%), and of these cases, re-operation was required in $1.8 \%$. From this meta-analysis, the conclusion that subtotal cholecystectomy is an important tool for use in difficult gallbladders that achieves morbidity rates comparable to those reported for total cholecystectomy in simple cases was reached. However, besides the advantages obtained in the early period by not dissecting hilar structures in these patients, there is a risk of cholecystitis symptoms recurring in the future, which is directly related to the amount of remnant gallbladder and the risk of the development of biliary pancreatitis and choledocolithiasis. Therefore, in some cases where partial cholecystectomy was performed, re-operation may be necessary for the remnant gallbladder $(5,9)$.

In the case presented here, the symptoms of cholecystitis continued in the postoperative period, for which antibiotherapy was received twice at different clinics. However, as acute cholecystitis developed in remnant gallbladder after the partial cholecystectomy, an adjacent intra-abdominal abscess formed. There was a lack of knowledge of the patient's previous operations, so the decision for surgery was taken on the assumption of the abscess and mass in the gallbladder. After intraoperative evaluation, a confirmed diagnosis was made, and a completion cholecystectomy was performed. When there are recurrent symptoms in patients who underwent partial cholecystectomy, evaluation should be made considering these complications.

When the diagnosis is preoperatively made, laparoscopic excision of the remaining tissue can be planned. However, there is a high possibility that the operation will need to be changed to open surgery because of potential adhesions (9). In the case presented here, there was a very low possibility of a laparoscopic operation because of adhesions and the location of the abscess.

\section{CONCLUSION}

It must be kept in mind that complications may develop associated with the remaining tissue in cases of partial cholecystectomy, and therefore, surgical intervention may be necessary.

Informed Consent: Written informed consent was obtained from patient who participated in this case.

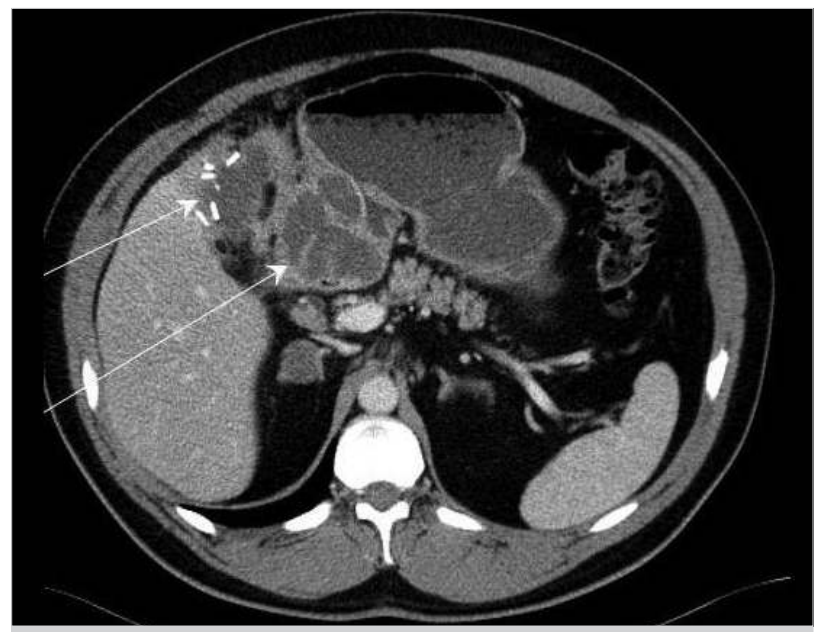

Figure 1. Abscess areas adjacent to the remnant gallbladder

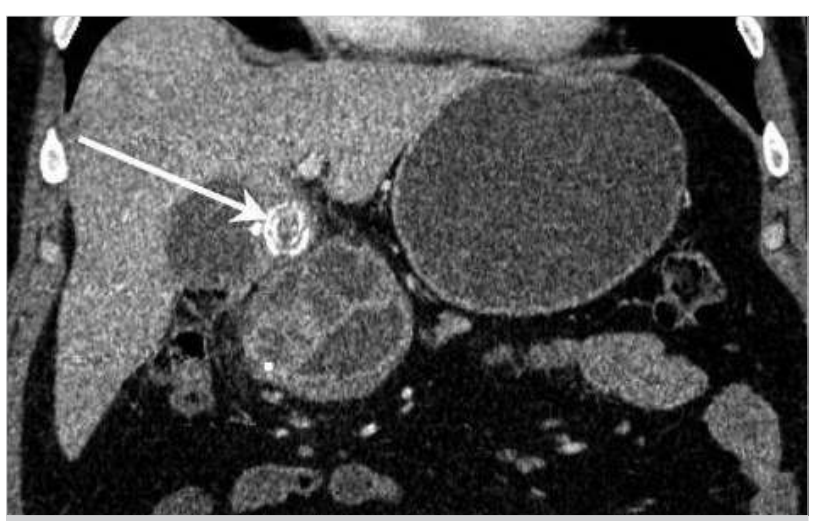

Figure 2. Stones in the remnant gallbladder and adjacent abscess areas

Peer-review: Externally peer-reviewed.

Author Contributions: Concept - O.K., H.P., M.Z.S.; Supervision - O.K., M.Z.S., M.F.B., M.B.; Funding - M.F.B., G.Ç., H.P.; Data Collection and/ or Processing - O.K., M.F.B., G.Ç.; Analysis and/or Interpretation - O.K., M.Z.S., H.P., M.B.; Literature Review - M.F.B., G.Ç., H.P., O.K.; Writer - O.K.; Critical Review - M.B., M.Z.S., H.P., G.Ç.

Conflict of Interest: No conflict of interest was declared by the authors.

Financial Disclosure: The authors declared that this study has received no financial support.

\section{REFERENCES}

1. Kaplan D, Inaba K, Chouliaras K, Low GM, Benjamin E, Lam L, et al. Subtotal cholecystectomy and open total cholecystectomy: alternatives in complicated cholecystitis. Am Surg 2014; 80: 953955.

2. Nakajima J, Sasaki A, Obuchi T, Baba S, Nitta H, Wakabayashi G. Laparoscopic subtotal cholecystectomy for severe cholecystitis. Surg Today 2009; 39: 870-875. [CrossRef]

3. Ibrarullah MD, Kacker LK, Sikora SS, Saxena R, Kapoor VK, Kaushik SP. Partial cholecystectomy--safe and effective. HPB Surg 1993; 7: 61-65. [CrossRef]

4. Soleimani M, Mehrabi A, Mood ZA, Fonouni H, Kashfi A, Büchler $M W$, et al. Partial cholecystectomy as a safe and viable option in the emergency treatment of complex acute cholecystitis: a case series and review of the literature. Am Surg 2007; 73: 498-507.

5. Sosulski A, Fei J, DeMuro J. Partial cholecystectomy resulting in recurrent acute cholecystitis and choledocholithiasis. J Surg Case Rep 2012; 2012: 17. [CrossRef] 
6. Yetim I, Dervişoğlu A, Karaköse O, Büyükkarabacak Y, Bek Y, Erzurumlu K. Laparoscopic cholecystectomy results in patients with different age groups. J Clin Anal Med 2011; 2: 75-78. [CrossRef]

7. Aydın Ç, Aytekin F, Tekin K, Yılmaz S, Kabay B, Sungurtekin U, et al. Laparoscopic cholecystectomy in the elderly. Ulus Cerrahi Derg 2005; 21: 179-183.
8. Elshaer M, Gravante G, Thomas K, Sorge R, Al-Hamali S, Ebdewi H. Subtotal cholecystectomy for "difficult gallbladders": systematic review and meta-analysis. JAMA Surg 2015; 150: 159-168. [CrossRef]

9. Cawich SO, Wilson C, Simpson LK, Baker AJ. Stump cholecystitis: laparoscopic completion cholecystectomy with basic laparoscopic equipment in a resource poor setting. Case Rep Med 2014; 2014: 787631. [CrossRef] 